\title{
Maine
}

\section{Coastal Wetland Issues}

The information in this fact sheet describes some of the ongoing U.S. Geological Survey (USGS) activities in Maine. The USGS provides reliable and impartial scientific information to partners and to the public. Policy makers and partners use USGS information to make informed decisions and to effectively manage natural resources.

Wetlands border 20 percent of Maine's shoreline and contribute vital functions to its coastal zone, including buffering adjacent uplands from erosion and supporting fish and wildlife. These same coastal marshes have been altered by man's use of the land from historical to present times. These alterations include historical ditching of marshes for salt hay farming and more recent development of adjacent uplands. Consequences include lowered water tables, degradation of fish and wildlife habitat, nutrient-laden runoff from surrounding areas, and potential changes in water chemistry. The USGS is studying wetland responses to various impacts and is evaluating techniques to restore the values and functions of these systems.

At Rachel Carson National Wildlife Refuge in southern Maine, the USGS is cooperating with the U.S. Fish and Wildlife Service to evaluate the technique of plugging drainage ditches to re-establish natural hydrology and enhance fish and wildlife habitat. By measuring the effects of ditch plugging on the physical, chemical, and biological aspects of marshes, this study will help deter-

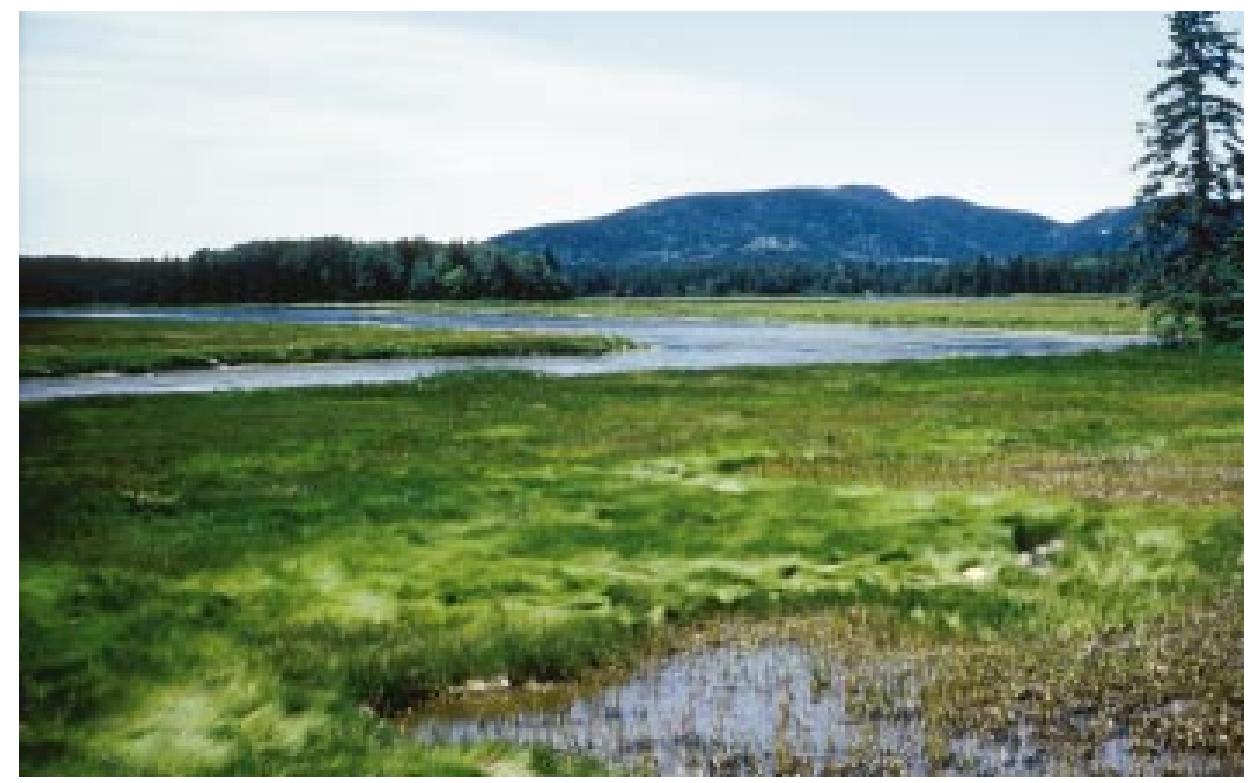

Figure 1. Bass Harbor Marsh at Acadia National Park, M aine

mine the broad applicability of this habitat restoration method.

The USGS also is cooperating with the National Park Service on several investigations at Acadia National Park (fig. 1). At the Northeast Creek wetland complex on Mount Desert Island, the USGS is quantifying nutrient inputs from streams, groundwater, atmospheric, and oceanic sources to evaluate potential effects of surrounding land-use changes. Habitat maps are planned as a baseline for continuing studies of wetland ecological functions.

As part of its statewide survey of mercury contamination in aquatic systems, the USGS evaluated mercury contamination in fish collected from lakes and ponds at Acadia National Park. Atmospheric deposition was found to be sufficient to account for mercury levels in the fish.
Examination of lake and bog sediment cores showed that mercury levels began to increase about the year 1900 and reached a peak about 1970. This contamination probably was related to human activity. The accumulation and transfer of mercury through aquatic insects to tree swallows are being studied.

The USGS also is cooperating with the National Park Service and the University of Maine to monitor nutrient concentrations in small streams of Acadia National Park. Large forest fires in the early 1900's altered the landscape of Mount Desert Island. More recently, areas adjacent to the Park have experienced substantial development pressures. Results of this monitoring will be used to evaluate the effects of land use and historical burning on nutrient loads to coastal environments. 


\section{Restoring Upriver Access for Maine's Fish}

The 162-year-old Edwards Dam on the Kennebec River in Augusta, Maine, is a significant barrier to fish migration. In 1997, the Federal Energy Regulatory Commission ordered the future removal of the 917-foot-long, 24-foot-high structure. Removal of the dam will restore the river's natural channel from Waterville to the sea, benefitting searun fish species native to the Kennebec. One concern with removal of the dam, however, is the character of the sediment in its impoundment.

The USGS, in cooperation with the State Planning Office and Maine Geological Survey, collected geophysical data to describe the character and distribution of sediments upstream from the dam. The data were used to map the areal extents of all river-channel sediment types (fig. 2) and to quantify the volume of mud and silt behind the dam. This information will aid in the development of an engineering plan for dam removal.

Removal of the Edwards Dam will enhance restoration of fish that migrate from marine to fresh waters to spawn. The USGS is examining the habitat requirements of these fish species native to the river. Atlantic salmon normally spend 2 years in fresh water before migrating to sea as smolts. The USGS is studying the effects of temperature and flow on migration and survival of Atlantic salmon smolts. Juvenile Atlantic sturgeon also have an extended residency in fresh water, and their habitat requirements are being investigated.

\section{Bald M ountain Mineral Deposit}

The USGS, in cooperation with NNM Resources, Inc. (a subsidiary of Black Hawk Mining, Inc. of Toronto),

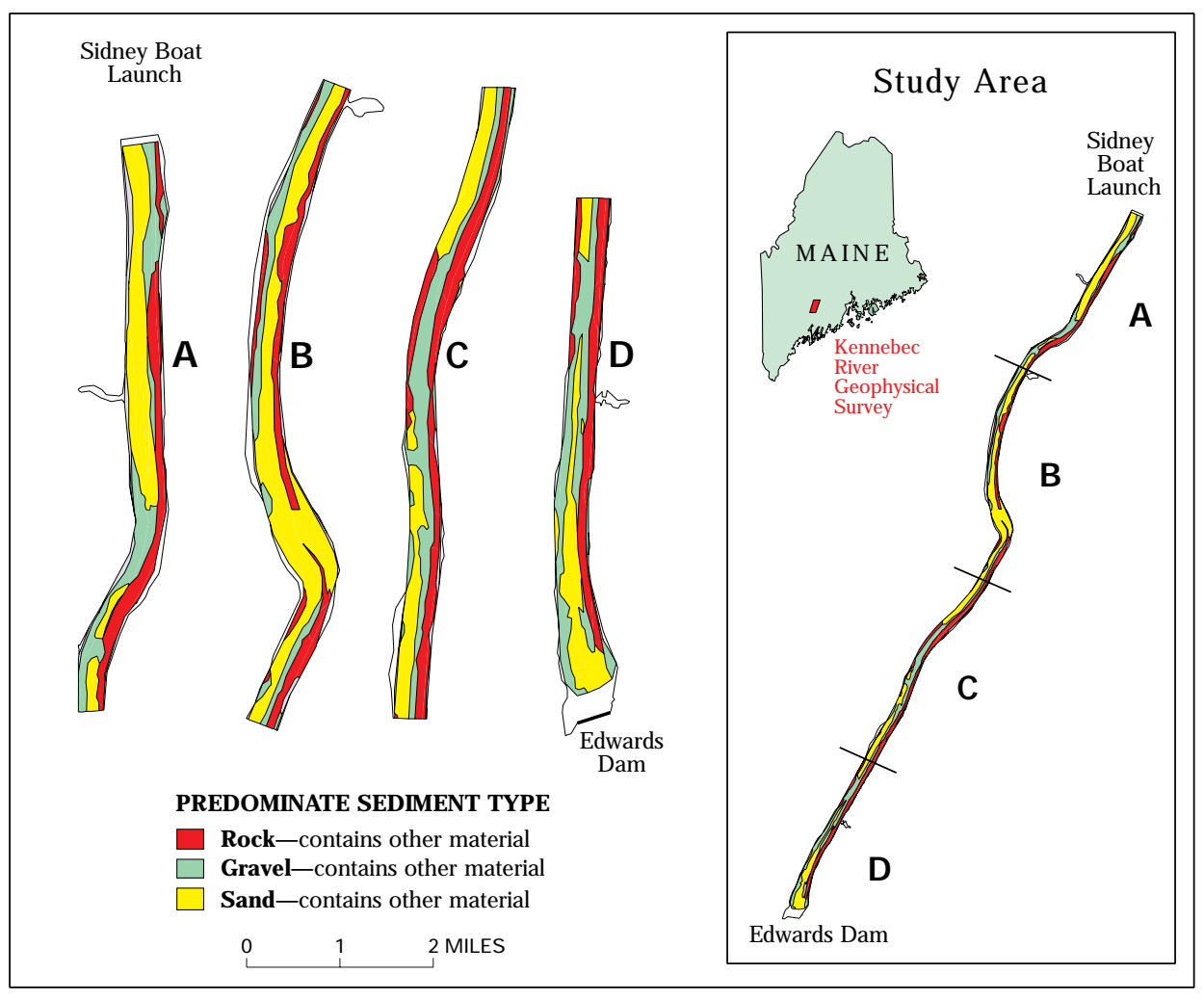

Figure 2. M ap of riverbed sediment in the Edwards Dam impoundment on the Kennebec River, M aine

Maine Geological Survey, and other partners, is conducting a study on the Bald Mountain deposit in northern Maine. This unmined deposit of copper, zinc, gold, and silver was formed in association with volcanic processes. Because this deposit is relatively undeformed, it provides a rare opportunity to address questions about its formation. The USGS also is characterizing the natural chemical signatures associated with this type of deposit, and determining what conditions and processes affect the long-term mobility of heavy metals in the weathering environment. This information will help refine models for the formation and weathering of this type of mineral deposit in the Eastern United States, and thus aid mineral exploration and also mineralresource and environmental assessments.

\section{Flooding}

Near realtime hydrologic data from the USGS streamflow gages (http:// me.water.usgs.gov) are used by the National Weather Service to help predict the size and timing of floods for certain rivers in Maine. For latewinter and spring flooding, it also is important to know how much water is contained in the snowpack. The Maine Cooperative Snow Survey (http://www.state.me.us/mema/snow/ snow.htm), jointly run by the USGS and the Maine Geological Survey with the help of many cooperators, measures the amount of water in the snowpack in late winter and early spring on a weekly basis (fig. 3). The National Weather Service computer model used for flood predictions is more accurate with use of the streamflow and snow data.

The USGS, in cooperation with the Maine Department of Transportation (MDOT), is developing better ways of estimating peak flows, such as the 100 -year peak flow. This will allow 


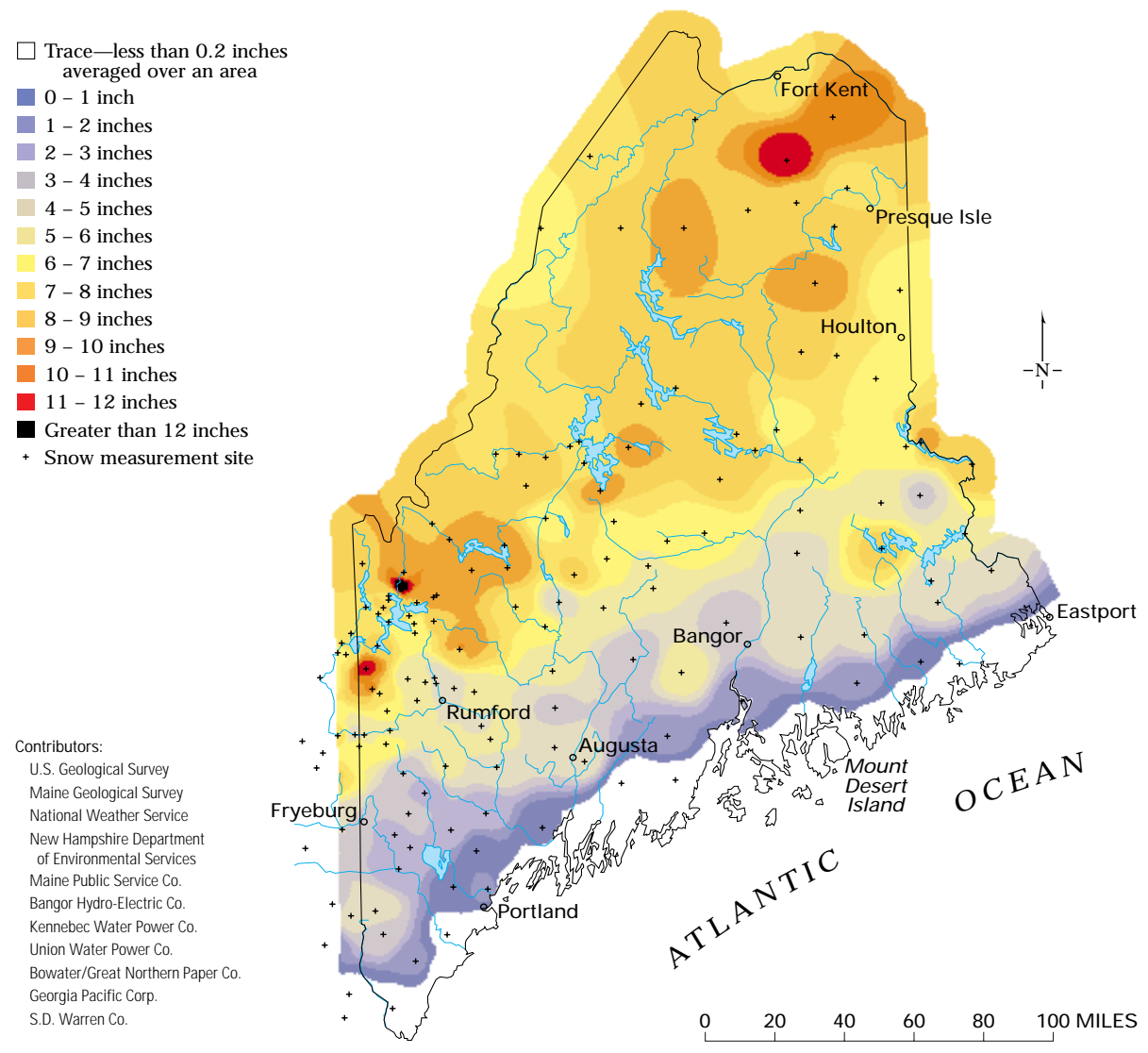

Figure 3. M aine Cooperative Snow Survey Program, Equivalent water content in snow pack (in inches)- M arch 2-4, 1998

improved designs for bridges and other hydraulic structures.

Another project with MDOT addresses the problem of pier scour at bridges. During floods, the streambed around bridge piers can erode. In extreme cases, this erosion can cause a bridge to collapse. The standard methods to predict how much pier scour is likely to occur at a bridge are based primarily on laboratory research. The USGS is measuring the actual pier scour at Maine bridges during floods to assess the accuracy of these methods.

\section{Black Duck Studies}

The continental population of the American black duck (fig. 4), after a 30 -year decline, stabilized in the early 1980's when more restrictive harvest regulations were initiated. Some still speculated, however, that mallards were competitively excluding black ducks from fertile wetlands, thereby reducing the numbers of young that black ducks were able to produce. Working with the Maine Department of Inland Fisheries and Wildlife, USGS scientists determined that mallards were not excluding black ducks from fertile wetlands. Furthermore, no difference was detected between black ducks and mallards in average brood size (4-5) on a range of wetland types in northern Maine. These data refute the hypothesis that competitive exclusion of black ducks from fertile wetlands caused the longterm population decline. Based on these data and other information, an International Black Duck Harvest Management Strategy Committee, recommended by the Black Duck Joint Venture (North American
Waterfowl Management Plan) and the Atlantic and Mississippi Flyway Councils, is now debating a continental harvest strategy to protect black ducks on primary breeding and staging areas to achieve population goals.

\section{MTBE in a Maine Aquifer}

Some areas of the United States that use MTBE (methyl tert-butyl ether) in reformulated gasoline have low $(<2 \mathrm{ppb})$ levels of MTBE in shallow aquifers that do not seem to be attributable to point-source contamination. Atmospheric deposition, through rainfall, may be responsible for this low-level contamination. The USGS, in cooperation with the Maine Department of Environmental Protection and the Town of Windham, is studying whether these levels of MTBE are found in a shallow sand and gravel aquifer in Windham, and whether air and precipitation in the area contains MTBE in sufficient amounts to account for any low-level contamination.

\section{Gulf of Maine "Red Tide" Blooms}

The USGS is cooperating with Bigelow Laboratory for Ocean Sciences, University of Maine, and other partners to understand the ecology and oceanography associated with toxic "red tide" blooms in the Gulf of Maine. The toxic blooms affect primarily shellfish, which if ingested by humans or other mammals can result in paralytic shellfish poisoning. The blooms are associated with numerous economic and public health issues along the Maine coast. During 1 year of high toxicity, $\$ 8-10$ million in shellfish revenues are lost.

USGS scientists are providing measurements of water properties and currents from moorings in the ocean and is codeveloping a coupled 


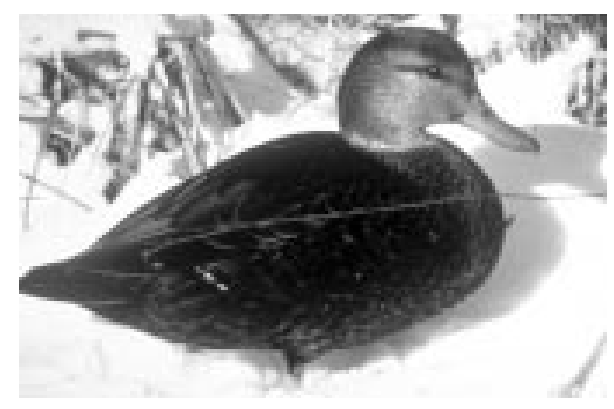

Figure 4. American black duck

biological/physical model with Woods Hole Oceanographic Institution to study processes controlling the initiation and evolution of red tides. Field data collected during April-July 1998 suggest that shellfish-toxicity events in the western Gulf of Maine may originate offshore. This has prompted Maine to consider future shellfish-toxicity monitoring stations offshore and on islands to act as an "early warning system."

\section{Habitat Map of Maine Completed}

The USGS and the University of Maine have completed a map of Maine's vegetation and land cover. The map was made as part of the Maine Gap Analysis and is accessible on the internet at http://wlm13. umenfa.maine.edu/progs/unit/gap. The map shows 19 types of upland vegetation and land cover, and 18 types of water and wetlands. It was created as a basis for predicting and assessing the distribution of non-fish vertebrates that regularly breed in Maine, but the map has many other uses. For example, scientists at the Maine Department of Inland Fisheries and Wildlife and USGS are using the map as a basis for jointly conducting detailed habitat assessments for selected wildlife species.

\section{USGS Mapping}

In 1998, the Maine Office of Geographic Information Systems (OGIS) provided the USGS with elevationcontour-line data in digital format. The USGS used these data to produce digital elevation models (DEM), which are digital files of terrain elevations for ground positions at regularly spaced horizontal intervals. DEM's can be used to generate threedimensional graphics displaying the topography of an area. This datasharing partnership with OGIS enabled the USGS to use previously produced State data to significantly reduce DEM production costs. Statewide DEM coverage is now complete and available to the public for use in geospatial modeling and analysis.

The USGS collected new black-andwhite aerial photographic coverage of Maine between 1996 and 1998. In cooperation with the U.S. Department of Agriculture, the USGS is using these photographs as image sources for digital orthophoto quadrangles (DOQ) of central and eastern Maine. The DOQ's are digital images of aerial photographs that have the geometric qualities of a map. The USGS is planning to work with its partners to update many of the Maine 1:24,000-scale topographic maps using the new DOQ's.

The USGS, in cooperation with State agencies and universities, distributes state-specific natural science products. The Maine Department of Conservation's Maine Geological Survey provides information about Maine's geology from its office in Augusta. This office sells USGS topographic maps in addition to their own publications (web site address: http://www.state.me.us/doc/nrimc/ nrimc.htm). The Maine Office of GIS provides digital geospatial data on its web site at http://apollo.ogis. state.me.us, including USGS coverages for the State of Maine.

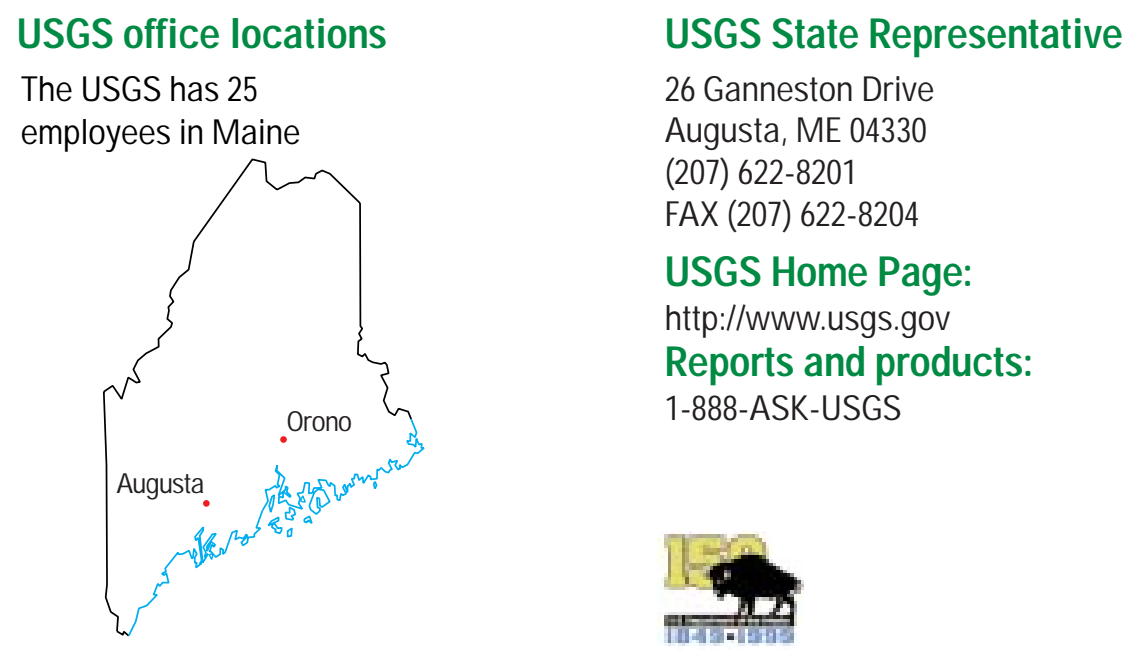

